\title{
THE IMPACT OF ENGLISH ON CUBAN SPANISH: A GLOSSARY-BASED ANALYSIS OF ADAPTATIONS ON THE SEMANTIC LEVEL (PART 2)
}

Keywords: Cuban Spanish, anglicisms, contrastive glossary, lexico-semantic analysis

\begin{abstract}
This article is intended to explore the linguistic means of anglicization in Cuban Spanish. Thus, a corpus-driven database or glossary of this variant of Spanish has been elaborated to examine these English-induced units quantitatively and qualitatively, entailing a morpho-syntactic and semantic analysis of the anglicization process. This research study is based on two major stages: data collection and data processing of the lemmas compiled. The resulting glossary of this part of the study is used to unravel the semantic traits of the English-induced units, chiefly related to the processes of polysemy and calquing. A compilation of these Cuban-Spanish anglicisms leads to a better understanding of meaning extension and lexical creativity, in keeping with the historical socioeconomic conditions of the island. The collection of colloquialisms, vulgarisms or obsolete words corroborates the diastratic and diaphasic evolution of lemmas, and unveils some distinctive word-building patterns.
\end{abstract}

\section{Direct and indirect borrowings}

\subsection{Indirect lexical borrowing}

Following the extraction of Cuban Spanish anglicisms from various sources (DPFC 1875; Marinello 1926-1927; NCC 1974; Santiesteban 1985; Cárdenas 1999; DMC 1999; Guerrero et al. 2003; DEC 2003; González Mafud 2010; CDCE 2012; CORDE 2014; CREA 2014; DLE 2014; GDA 2017), the analysis and typology of the lexico-semantic variants shows that $23.8 \%$ of these units are indirect lexical borrowings, namely 
calques (loan translation, loan rendition, loan creation) and semantic loans. The study confirms that semantic loans account for nearly half of the indirect loans found (see Figure 3).
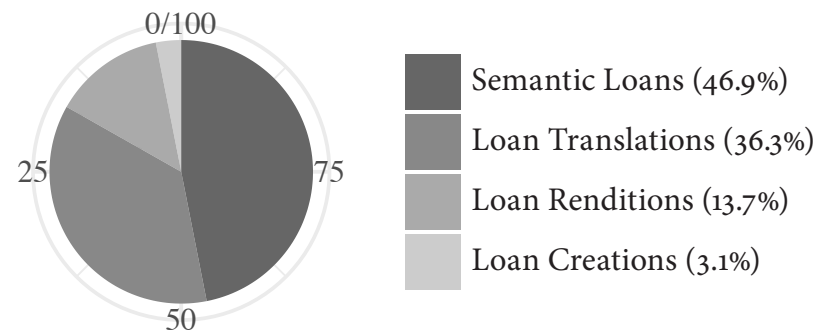

Figure 3. Distribution of indirect lexical borrowings in the database

Semantic loans have been continuously characterized by adjusting into the language under native morphological structures. This is precisely what characterizes semantic loans (or calques) as a perfect "camouflage" in terms of language contact and linguistic assimilation, e.g. amarillo 'coward' < yellow; asumir 'to suppose' < to assume; cellular < cell (phone); cebra < zebra crossing; chivo < goatee; diamante 'baseball ballpark' < diamond; iluminaciones < (hair) highlights; pasaje < passageway; rayo $<$ (bicycle) ray; remover 'to move from a prior position' $<$ to remove. These native lexical units undergo a process of semantic extension, in which Spanish senses are complemented by the addition of imported meanings. These calques, or translations, are occasionally accompanied by morphological variations (clipping, ellipsis, etc.), which are intended to "hispanicize" the loans even more thoroughly: passageway $\rightarrow$ pasaje, zebra crossing $\rightarrow$ cebra.

Loan translations are less common than semantic loans in Cuban Spanish, and the resulting unit is the product of a literal translation of the English counterpart: aeromoza < air hostess, arco del pie < arch of the foot, bateador emergente < emergent batter, bola de tenedor $<$ forkball, calle ancha $<$ broad way, cortina de hierro ${ }^{1}<$ iron curtain, cuello-tortuga < turtleneck, Grandes Ligas < Major Leagues, hospital de día $<$ day hospital, mesa sueca 'buffet' < Swedish table, novela jabonera < soap opera, perro caliente < hot dog, queso crema < cream cheese, rabo de nube < tail cloud, robar base < to steal a base (in baseball), rompequijá 'hard candy' < jawbreaker, tienda por departamentos < department store. A number of these lemmas are compound units, which might explain the literal calquing of their English paronyms, and the major changes language might go through to compensate the absence of such signifiers in the system.

Loan renditions and loan creations are noticeably less frequent, but their transformations imply a higher degree of creativity and nativeness. The former results from an approximate translation of its components (Martinet 1960: 170; Weinreich 1968: 62):

1 In Sp., the equivalent would be telón de acero, which is a loan rendition, rather than a loan translation. 
bocadulce $<$ sweet tooth, cheque de retención $<$ retention check valve, círculo de espera $<$ deck circle, cremería < ice-cream parlor, patear la lata 'to die' < to kick the bucket, polo acuático $<$ water polo, presión arterial < blood pressure. Loan creations show no strict or literal resemblance to their English paronyms, as in the following baseball positions: inicialista 'a baseball position' < lead-off, jardinero central $<$ center-fielder, jardinero izquierdo/derecho $<$ leftlright fielder, serpentinero $<$ pitcher, sirvase-usted $<$ self-service restaurants. These units confirm the complexity of the calquing process within the target language, honed by a significant semantic motivation. The use of jardinero in baseball is probably motivated by the 'green grass' in the fields, which coexists with the adapted form fildeador. The case of pitcher is of a more complex nature: serpentinero is derived from serpentina 'streamer', which depicts pitchers' throwing. These infrequent, but highly complex constructs, are also intended to facilitate the assimilation of English concepts by resorting to calqued native forms.

\subsection{Direct borrowings}

Direct borrowings, on the contrary, are easier to spot. A comprehensive analysis of the lexico-semantic variants compiled in the glossary (cf. DELCS 2017) shows that the majority of these English-induced units correspond to direct lexical borrowings $(76.2 \%)$. A more detailed revision of the data reveals that $78.2 \%$ of these direct forms are precisely loanwords, both adapted and non-adapted forms.

As described earlier in Part 1, loanwords are anglicisms par excellence, especially those forms lacking any major variations in their original form (non-adapted): all right, aqualung, baby-doll, balk, big leaguer, blueplate, breaker 'a device for opening a circuit', cameraman, catcher, clinch, closet, display, extrainning, fly 'a hit high into the air', high life, hot cake, laptop, lollipop, mouse, off side, outfield, pent-house, play-off, power, ready, rocket, safe, short stop, spot 'TV or radio commercial', tie break, vinyl. All these forms are primarily unchanged in terms of spelling and pronunciation. However, a few of non-adapted loanwords may show variations with regard to pronunciation: average /aßeráxe/, back-up /bakúp/, baffle /báfle/, double play /dòßle pléi/, garaje 'a shop where vehicles are repaired'/garáxe/, rash/rás/.

The present quantitative analysis of adapted loanwords merely relies on spelling variations. In other words, adapted loanwords are considered lexical units whose spelling has been modified: ampaya < umpire, bacha 'a noisy get-together' < batch, bisnero < business, bugalú < boogaloo, chalina $<$ shawl, escauteo 'the act of gathering information before a game to make the right decision' < scout, finta < feint, güito 'whitish spots on the skin' $<$ white, jaba $<$ handbag, noquelbol $<$ knuckleball, paco $<$ pack, payama < pajamas, plomero < plumber, ponche 'a flat tire' < punch-out, raspe $<$ rasp, relé $<$ relay, siol 'the player who defends the area between the second and third base' $<$ short stop, soque $<$ socket, trole $<$ trolley, yaqui 'one of the pieces used to play in a children's game' < jack, ziper < zipper. As noticed, some of these borrowings could have undergone minor pronunciation variations. The scale of spelling changes varies from easily perceptible (payama, raspe, ziper) to highly "camouflaged" ones (chalina, jaba, siol). 
False loans, or pseudo-anglicisms, are significantly diverse. These forms, recognizably English in their form, are used with a different meaning in English: antifrizer $<$ antifreeze, bate 'penis' < bat, bayú 'brothel' < bayou, blof 'an arrogant person' < bluff, center 'the player defending the centre field' < centre field, collin 'a machete' < Collin, corring 'the act of running from base to base' < correr 'run' + -ing, eslogan 'perfect' < slogan, floor 'basketball court' < court floor, gungadín 'mulatto' < Gunga Din, high 'upper economic stratum' < high class, kinder < kindergarten, licra 'a pair of leggings' < lycra, overjol 'a complicated surgery' < overhaul, panel < panel truck, rolling < roller or roll-out, zambrán 'a wide belt' < Sam Browne.

\section{Semantic analysis}

\subsection{Semantic fields}

The study shows that the commonest semantic fields are: sports $(21.7 \%)$, clothes (6.8\%), technical words (5.3\%), food (5.2\%), transport (3.8\%), home appliances (3.4\%), medical terms/body (2.1\%) and occupations (1.7\%). All these figures are sketched numerically hereafter, in Figure 4.

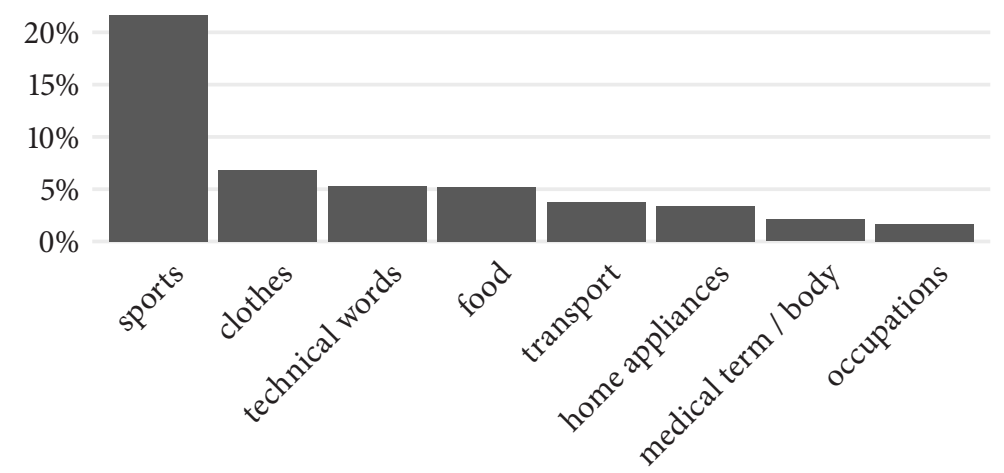

Figure 4. Commonest semantic fields in the corpus

The semantic field of sports is by far the commonest one extracted, chiefly baseballrelated units: batear < to bat, jonrón < home-run, out, montículo < mount, pitcher, rolling. Therefore, baseball has played a fundamental role in the anglicization process of Cuban Spanish by assimilating a number of expressions and words, whose literal meanings are at times modified or extended, and widely used in the Spanish vernacular. Other terms were also found: clinch (boxing), handball, light welter (boxing), noquear (boxing), polo acuático < water polo. The influence of baseball-related anglicisms is not restricted to Cuban Spanish: other neighbouring countries are also known for "importing" a large number of these terms, e.g. Colombia, Venezuela, Dominican Republic, Costa Rica, etc. (cf. Fernández 1971; González Gómez 1998; Alba 2007).

Due to the aforementioned influence of American English, it is not unexpected to find a number of English-induced loanwords related to the semantic fields of clothing 
and fabric types. Most fabric names remain as technical terms within the clothing industry (guingham, broadcloth, galalith, heatherspun) whilst others have been thoroughly assimilated into the vernacular, which is somehow noticeable in spelling shifts (linin, chantung < shantung, guarandol < warandol, linolán $<$ linoleum, yersi $<$ jersey). Clothing items have been more easily adapted into the Cuban variant: jacket (or yaqui), suéter < sweater, pulóver < pull-over, blazer, blúmers or bloomers.

A number of technical words and expressions are present in various domains: alimentador de caña < cane feeder (sugar cane industry), balancear 'to make car wheels steady by keeping weight equal on all sides' < to balance, caja decodificadora $<$ decoder box, kilowatt, macadán 'a road surface made with a dark material that contains small broken stones' < John Mac Adam.

Curiously, many adapted food-related units have been found, mostly coined in Neocolonial times (1902-1958): cake, coffeecake or cofiquei, frozen 'ice-cream served in a wafer' < frozen ice-cream, láguer 'beer' < lager, malta 'fizzy drink made of malt' $<$ malt, soda, mesa sueca < Swedish table, panqué < pancake, peter 'chocolate bar' < Peter Paul. Interestingly, loanwords like láguer < lager and soda, initially hyponyms of types of beer and fizzy drink respectively, have evolved into hypernyms.

Similarly to the other semantic fields described, finding a number of transportrelated borrowings reflects the high degree of influence exerted by the American car industry throughout the Neocolonial period. The words extracted show a supremacy of adapted forms: carro < car, cloche < clutch, emergencia < emergency brake, flashear 'to signal turnings in a car' $<$ to flash, antifrizer $<$ antifreeze, serviciar $<$ to service (a car).

A few of the house-tagged lemmas are invariably linked with generic trademarks: ace, fab, frigidaire, yale 'door lock'. The majority of the entries were obviously imported during the rise of North-American trading before 1959: boxspring $<$ box spring, breaker 'circuit breaker', buró < bureau, car porch, catao < cut-out box, chifforober < chifforobe, closet, freezer, juego de living 'living-room set', mezzanine, penthouse, socket.

Some medical terms or body-related nouns are grouped into a single semantic field. The number of lemmas found is much lower than the rest of the fields, and some of them are visibly the product of calquing: arco del pie < arch of the foot, constipación 'being unable to release solid waste' $<$ constipation, doble barba $<$ double-chinned, güito 'whitish spots on the skin' < white, ojo de pescado 'skin warts' < fish eye, presión arterial $<$ blood pressure, rash, tonsila $<$ tonsils, quiropedia $<$ chiropody.

Some of the entries related to "occupations" denote unknown concepts in Cuban Spanish: cameraman, despedidor < (bus) dispatcher, reporter, steward(-ess), tipista $<$ typist, yatista $<$ yacht. These are complemented by derivatives, originally formed from loanwords (adapted or not): güinchero < winch, lonchero 'someone who works in a cafeteria and is responsible for preparing sandwiches and snacks' $<$ lunch, panquelero $<$ pancake, parqueador $<$ to park, trailero $<$ trailer, pipero 'someone who is responsible for driving a tanker truck'<pipe. The last example, pipero, is of curious nature: it is derived from the loanword pipa < pipe, which is one of the parts making up the whole of a tanker truck. This synecdoche is also transferred 
to denote what is contained: refresco/cerveza/malta de pipa 'soft drink/beer/malt stored and distributed by tanker trucks'.

The study of anglicisms through these semantic fields could be an effective tool to have a better picture of the sociolinguistic influence American English might have had on Cuban Spanish, especially in the Neocolonial period. Pastimes, technology and fashion are precisely those fields in which the highest number of anglicisms has been expectedly attested. These fields are tightly linked with the upper socioeconomic stratum, which corroborates prior studies on the role played by empowered social classes in pre-1959 Cuba in the anglicization of the language, manners and culture (cf. Sánchez 2016).

Based on the sources consulted, a total of 122 lexico-semantic variants have been labelled as colloquialism, which accounts for nearly $12.3 \%$ of the senses. This number confirms the sociolinguistic relevance of English-induced linguistic borrowing in $\mathrm{Cu}$. colloquial and slang speech. The majority of the colloquialisms extracted are precisely metaphorical senses of already-imported anglicisms. The example of bateo $(<b a t)$ certainly illustrates this pragmatic change; in its more literal sense, it refers to the act of hitting the ball into the infield as in:

La selección cubana sufrió este jueves su segunda derrota en el Campeonato Mundial de Béisbol, categoría sub-12, con sede en Taipéi de China, al caer con marcador de 4-o ante Nicaragua, en duelo correspondiente a la segunda ronda. ("Cuba: escaso bateo y pobre defensa", www.juventudrebelde.cu, 31/07/2015)

This meaning, intended to denote a more technical concept in baseball, contrasts with its second lexico-semantic variant described. The latter one makes reference to the action of causing trouble or hassle, which is supplemented by collocates (dar or meter bateo) as in:

Iba y metía unos bateos por la noche según me decía la madre al día siguiente, que no eran fáciles. Pero bueno, a lo mejor yo estaba confiado, no me despertaba porque estaba confiado en que la madre era la que se despertaba y la atendía por la noche cuando gritaba. (González Mafud 2010: 146)

This process of semantic shifting is not precisely coincidental. It is determined by a metaphorical transfer of traits from a literal sense ('hitting the ball to the infield so the other team loses') to a more figurative one ('saying or doing something so that the other person is in trouble'). In a number of figurative or metaphorical variants, the semantic extension of the units is motivated by certain salient features of the etymon: bayú (< bayou) 'a brothel' $\rightarrow$ 'a commotion or uproar, especially among non-educated peers', bombero (< fireman) 'a relief pitcher who is brought in to end the game' $\rightarrow$ 'someone capable of solving problems in an efficient manner', ponche $(<$ punch) 'the result of striking out three times in a row, in a baseball game' $\rightarrow$ 'a failing mark at school'.

Due to the dia-synchronic nature of this research, some written materials (periodicals), issued in pre-1959 times, have also been revised. One of the most significant findings is the number of obsolete English-induced units ( 73 lemmas), the majority 
of which were extracted from Neocolonial papers: at home, baby shower, barbecue, bowling, boy-scout, brass, bride maid, broadcloth, buffet supper, bunch, club house, clubman, cocktail party, cocoa, dry cleaning, easter lilies, fraternity, French poodle, galalith, heatherspun, high-ball, jack pot, jazz-band, junior bride maid, keno, kitchen shower, long cloth, lunch, maid of honor, mayor, minimum, mink, moss, orange, peach, privet, pump, push-pull, Queen Mary, revue, ring boy, roof garden, skating rink, slack, splash party, spun, steward, stewardess, sweet heart rose, sweet peas.

These obsolete units reveal not only the aforementioned anglicization process of Neocolonial Cuban Spanish, but also how a number of loanwords, initially embraced by middle or upper-social class, fell out of use. One of the earliest results indicates a surprisingly high number of English loanwords in society columns and advertising, especially those related with weddings, birthdays, and christenings. Some of these lexical units were new cultural referents in Neocolonial Cuban Spanish (ring boy, flower girl) whilst others simply replaced already-existing units in the language (wedding cake as in tarta nupcial/de boda, baby as in bebé). After 1959, some of these referents (or cultural borrowings) were kept but their signifiers were modified:flower girl $\rightarrow$ damita, ring boy $\rightarrow$ damito.

The glossary also encompasses measuring system units, which were assimilated or calqued from English: yarda, pulgada, pie, libra $<$ yard, inch, foot, pound. Curiously, they all became obsolete after 1958, except for libra, which still co-exists with kilogramo.

Obsoleteness and semantic shifting are necessarily linked to sociolinguistics and pragmatics. The socio-economic transformations on the island after the 1959 Revolution, and the corresponding disappearance of traditional middle and upper social class, resulted in a dramatic shift in this word stock of English origin. This might explain why a number of already-coined loanwords fell out of use: kitchen shower, cocktail party, supper, grocery, wedding cake, etc. As expected, these units were mostly used by the empowered social strata. At times, new senses were originated under the same lemma, leading to homonymy: party 'refined social event in which upper social class members meet for entertainment' $\rightarrow$ 'an informal gathering of people in which music, food and drink are provided'; bunch 'a group of people' $\rightarrow$ bonche 'a street party'; gánster < gangster 'a member of a criminal gang' $\rightarrow$ 'someone who is known for his/her illicit activities'; bisne < business 'the activity of making, buying, or selling goods' $\rightarrow$ bisne 'an illegal activity that involves selling and buying'.

In general, these $\mathrm{Cu}$. phrases are not necessarily colloquial in English. Nevertheless, some expressions are found to be semantically coincident in terms of sociolect and register: cana 'prison' < can; amarillo 'cowardly' < yellow; barato '(referring to a person) vulgar or ill-mannered' < cheap; palanca 'a powerful person, used to achieved a desired result' < leverage; patear la lata 'to pass away' < to kick the bucket; tanque 'prison' < tank; venderse como pan caliente 'to sell well' < to sell like hot cake. Most of these expressions are visibly calques, which contrasts somehow with the anglicisms whose semantic structure has clearly undergone pragmatic variations, e.g. all right, bacha 'a noisy get-together' < batch, bonche 'a street party' < bunch, 
party 'an informal gathering', stand by'a period of time in which someone is waiting for the right time to do something. These examples are low-sociolect colloquialisms, as opposed to their analogous English forms.

\subsection{Interpreting semantic extension}

Whilst a number of units are shortened structures of existing English paronyms (e.g. centre < centre field, floor < (in basketball) court floor, panel < panel truck), others resort to English-like suffixes, or pseudo-suffixes, attached to a Spanish base (corring, gratindei 'free'). However, it is perhaps the extension of meaning that truly characterizes this type of direct lexical borrowing. The addition of senses might be owing to eponymy (gungadín, betibú 'a provocative woman' < Betty Boop ${ }^{2}$ ), metonymy (baffle 'outspeaker'), toponymy ( yuma 'the United States' < Yuma), etc. The semantic shifting through metonymy or synecdoche entails a wide range of cases: tomarse la coca cola 'to forget beloved people, especially relatives and friends' < Coca Cola (trademark), bul 'a refreshing drink which is made of beer or sparkling water, lemon, and sugar' $<$ bowl (container is used to denote what is contained), blower 'the act of blow-drying the hair' (instrument denoting the action). The last example portrays not only semantic shifting but also ungrammaticality in English: -er is not a wordbuilding suffix for action nouns.

A recurrent pattern in the glossary is the presence of pseudo-anglicization in polysemic lexico-semantic variants. These lemmas are usually characterized by outlining a loanword (adapted or non-adapted), and then a false loan, a semantic extension of a more literal one. For instance, clinch has been described as conveying two lexico-semantic variants. The second sense is clearly extended from the stricter meaning describing how boxers hold each other very closely during the round:

(sense 1) In boxing, a position in which both boxers are holding each other very closely.

(sense 2) The act of kissing or holding each other in a continuous manner.

A similar frequent patterning is also visible in indirect lexical borrowings: the stricter sense is a calque, chiefly a loan translation or loan rendition, whose meaning is noticeably shifted into a metaphorical sense, e.g. coger fuera de base. This type of lexico-semantic variant has been classed as "metaphorical calque", and it denotes a recurring process of semantic variation. Both senses have been extracted and detailed in the glossary because they are considerably relevant to study semantic shifting or polysemy/homonymy in lexical borrowing:

(sense 1) In baseball, to catch out a baseball runner for not being on base.

(sense 2) To surprise someone when he/she is doing something inadequate.

2 Animated cartoon character, created by Max Fleischer, and regarded as one of the first and most famous sex symbols of the animated screen. 
On the whole, metaphorical calquing is the product of translation and polysemy. The resulting constructs are probably the least easily perceived forms by English speakers, and they are widely found in the glossary: correr para tercera base 'to resort to mockery and evasion to do something' < to run to third base, base por bolas 'to allow someone to get away with it' < base on balls, esquina caliente 'a place in which controversial issues are discussed' < hot corner, bombero 'someone capable of solving problems' < fireman.

False loans and metaphorical calquing share a great deal of similarities. The former units are signifier-centred, i.e. a loanword is assimilated into Spanish but its meaning differs from its English counterpart. The latter process depicts the borrowing of a meaning, i.e. signified-centred, and its variations within the target language system.

\section{Conclusions}

The compilation of autochthonous Cuban Spanish anglicisms, i.e. a differentiating glossary, helps examine the nature of various concepts such as typology, frequency, productivity, etc. The resulting entries in the glossary, and the contrastive nature of the information provided, constitutes a comprehensive map of anglicization trends in Cuban Spanish, laying the groundwork for forthcoming comparative and normative studies.

The number of lemmas extracted was 818 , and the number of lexico-semantic variants (or senses), 984. The semantic variants sharing meaning with their European counterparts were not removed to have a better understanding of the phenomena of homonymy, polysemy and semantic transparency. A total of 74 idioms were also specified, being characterized by extending semantically from the lemmas, and by being typically related to baseball. These idioms are mostly colloquial, and their native syntax and adapted loanwords lead to fully integrated English-induced units: comerse un cake /kei/ 'to feel let down by something or another person' < cake.

The glossary-based information shows that nouns and noun phrases account for the majority of the lemmas found: 74.9\%. Apparently, the high number of Englishinduced nouns complies with one of the essentials of lexical borrowing: designating unknown referents in the target language. The majority of the nouns annotated are inanimate, which explains why the majority of them are considered patternless, contrasting with grammatically marked animate nouns.

The analysis of compounds has shown that most of the units extracted are graphemically unadapted units: baby-doll, background, handball. Though seemingly one-word loans, some bases are either strictly nativized: béisbol < baseball, dogao $<$ dug-out, or calqued: aeromoza < air-hostess, cargabates $<$ bat-carrier. These examples indicate how compound elements in a unit are also borrowed, leading to visibly ungrammatical units.

An analysis of the lexico-semantic variants compiled shows that $23.8 \%$ of the anglicisms are indirect lexical borrowings, i.e. calques (loan translation, loan rendition, 
loan creation) and semantic loans. Nearly half of the indirect loans correspond to semantic loans, confirming then its highly productive nature in Cuban Spanish. The assimilation of these units varies from slightly adapted, i.e. easily perceptible (payama $<$ pajama, raspe < rasp) to highly imperceptible (chalina $<$ shawl, jaba < handbag).

A recurring pattern refers to polysemic lemmas, whereby a stricter or literal sense is a calque, chiefly a loan translation or loan rendition, and a secondary sense is the result of metaphorical extension: correr para tercera base 'to resort to mockery and evasion to do something' < to run to third base. This type of lexico-semantic variant has been coined as "metaphorical calque". It has been singled out from the rest of semantic processes due to its high productivity and peculiarities. They originally stem from calquing and translation, and they are not easily discernible by English speakers. A vast majority of them corresponds to baseball-related idioms.

The study suggests that the commonest semantic fields extracted are sports, clothes, technical words, food, transport, home appliances, medical terms/body and occupations. The revision of these lemmas through semantic fields is crucial to comprehend the degree of sociolinguistic influence American English might have exerted on Cuban Spanish. Pastimes, technology and fashion are precisely those semantic fields in which the highest number of English-induced units has been attested.

The inclusion of obsolete English-induced units (137 lexico-semantic units compiled) results in a fine-grained diachronic study of semantic shifting, and in a precise depiction of the anglicization process in Neocolonial Cuban Spanish. The number of obsolete lemmas is 73 , the majority of which are related to fashion and social pastimes such as baby shower, bride maid, maid of honour. By tracing the evolution of these lexico-semantic variants through the historical periods in question, the correlation between the concepts of obsoleteness and semantic shifting is unraveled.

Without doubt, this analysis of the anglicization process in Cuban Spanish demonstrates the complexity of the sociolinguistic and pragmatic traits underlying the import of English words. This will also shed more light on how American English entered "into constructs of class, status, and nationality, whereby English usage signified an alternative that went beyond Spanish to reach out to an opposing cultural system" (Pérez 2008: 53).

\section{References}

CDCE 2012 = Basterrechea Sosa I. 2012. Cubaneando: diccionario cubano-español. Miami. CORDE 2014 = Real Academia Española. 2014. Corpus diacrónico del español. [http:// corpus.rae.es/cordenet.html; last access: June 23, 2017].

CREA 2014 = Real Academia Española. 2014. Corpus de referencia del español actual. [http://corpus.rae.es/creanet.html; last access: June 23, 2017].

DEC 2003 = Haensch G., Werner R. 2003. Diccionario del español de Cuba. Madrid.

DELCS 2017 = Sánchez Fajardo J.A. 2017. A Dictionary of 1,000 English Loan Words in Cuban Spanish With Usages, Synonyms, and Etymologies. New York.

DLE 2014 = Real Academia Española. 2014. Diccionario de la lengua española. [http:// www.rae.es/diccionario-de-la-lengua-espanola/la-23a-edicion-2014; last access: June 23, 2017]. 
DMC 1999 = Sánchez-Boudy J. 1999. Diccionario mayor de cubanismos. Miami.

DPFC $1875=$ Pichardo y Tapia E. 1875. Diccionario provincial casi razonado de vozes $y$ frases cubanas. [4 ${ }^{\text {th }}$ edition]. La Habana.

GDA $2017=$ Rodríguez González F. 2017. Gran diccionario de anglicismos. Madrid.

NCC 1974 = Ortiz F. 1974. Nuevo Catauro de Cubanismos. La Habana.

Alba O. 2007. Integración fonética y morfológica de los préstamos: datos del léxico dominicano del béisbol. - RLA 45.2: 89-109.

Cárdenas Molina G. 1999. Anglicismos en la norma léxica cubana. - Fuster M. et al. (eds.). Cuadernos de Filología IV. Valencia: 15-57.

Fernández García A. 1971. Anglicismos del deporte en Colombia. El béisbol. - Español Actual 19: 18-22.

González Gómez M. 1998. Anglicismos usados en narraciones costarricenses del béisbol. Káñina, Revista de Artes y Letras de la Universidad de Costa Rica 23: 91-99.

González Mafud A.M. 2010. Muestras del habla culta de La Habana. La Habana.

Guerrero Ruiz P., Pastor Pastor B., Depreste Catony L. 2003. Glosario popular cubano. Lenguaje y textos 20: 139-160.

Marinello J. 1926-1927. Un guacalito de cubanismos. - Archivos del Folklore Cubano 2-4: 108-119, 228-235, 363-368.

Martinet A. 1960. Eléments de linguistique genérale. Paris.

Pérez L.A. 2008. On becoming Cuban: Identity, nationality and culture. Chapel Hill (NC).

Sánchez Fajardo J.A. 2016. Anglicisms and calques in upper social class in pre-revolutionary Cuba: A sociolinguistic analysis. - IJES 16.1: 33-55.

Santiesteban A. 1985. El habla popular cubana de hoy. La Habana.

Weinreich U. 1968. Languages in contact. The Hague. 
